\title{
An exceptional find on rabbit dung from Italy : third record worldwide of Ascobolus perforatus
}

\section{Doveri F*}

Via dei Funaioli 22, I-57126-Livorno.

Doveri F. 2012 - An exceptional find on rabbit dung from Italy : third record worldwide of Ascobolus perforatus. Mycosphere 3(1), 29-35, Doi 10.5943/mycosphere/3/1/3

An on-going survey of coprophilous fungi from Italy has continued, resulting in reports of a new onygenalean taxon and a very rare Ascobolus species. The morphological characteristics of Ascobolus perforatus are described and compared with similar taxa. Additional differences between this species and another belonging to the same section of Ascobolus are provided from examination of two Italian collections. The likeness between Ascobolus perforatus and some Ascodesmis species is stressed and further proved by comparative colour figures obtained from Italian collections of Ascodesmis microscopica, A. nana, and A. nigricans.

Key words - Ascobolus - Ascobolus reticulatus - Ascodesmis - coprophilous fungi Pseudascodesmis.

\section{Article Information}

Received 07 January 2012

Accepted 11 January 2012

Published online 24 January 2012

*Corresponding author: Francesco Doveri-e-mail-f.doveri@sysnet.it

\section{Introduction}

My survey on coprophilous fungi from Italy (Doveri 2004, 2010, 2011) allowed me to recognise 92 Basidiomycota and 256 Ascomycota, the latter including 93 discomycetes s.l., particularly 37 species of Ascobolaceae Boud. ex Sacc. (16 Ascobolus Pers.; 12 Saccobolus Boud.; 9 Thecotheus Boud.), and 11 species of Ascodesmidaceae J. Schröt. (8 Lasiobolus Sacc.; 3 Ascodesmis Tiegh.). Since then my research has continued resulting in the classification of only two taxa new to Italy, Neogymnomyces virgineus Doveri et al. (2012), a new keratinolytic species from dormouse dung, and Ascobolus perforatus, a striking, very rare species with microscopic features similar to the genus Ascodesmis.

The aim of this work is to describe the morphological features of Ascobolus perforatus and to compare it with species in the same section of Ascobolus and in the genus
Ascodesmis in the light of several Italian collections.

\section{Methods}

Ascobolus perforatus was obtained from dried rabbit dung collected in Central Italy in March 2011 and placed in a non-sterilized damp chamber in December 2011, following the methods suggested by Richardson \& Watling (1997) and Richardson (2001), slightly modified by Doveri (2004). Cultured material, incubated at room temperature $\left(18-23^{\circ} \mathrm{C}\right)$ under natural light, but not exposed to direct sunlight, was examined every day using a stereomicroscope.

Mature ascomata, noticed after 25 days incubation, were picked up from the dung using a sterile needle, washed in sterile distilled water and then placed in a drop of sterilised distilled water on a microscope slide. 
Microscopic examinations were carried out on specimens mounted in water, Congo red, and Melzer's reagent.

Ascospore length and width were calculated on fifty ascospores discharged from mature asci in three ascomata; excluding ornamentations from measurements. Specimens were preserved both as dried material and slides in the author's personal herbarium (CLSM).

\section{Taxonomy}

Ascobolus perforatus Brumm., Persoonia 11: 356, 1981.

Figs 1-10

$\equiv$ Ascodesmis canina Jeng \& Cain, Mycotaxon 3: 392, 1976 (ut caninus).

Apothecia 400-700 $\mu \mathrm{m}$ diam., subglobose to pulvinate, pure to dirty whitish, membranous, smooth to sparcely and imperceptibly white hairy, with some rhizoids at their base. Margin not differentiated. Hymenial surface slightly convex, dark dotted owing to protruding asci. Subhymenium not differentiated from medullary excipulum. Medullary excipulum a textura angularis or subintricata of hyaline, thin-walled polygonal to subcylindrical cells, the latter perpendicular to the hymenial surface, 5-10 $\mu \mathrm{m}$ diam. Ectal excipulum a textura prismatica of hyaline, thin-walled, rectangular cells, up to 7 $\mu \mathrm{m}$ diam., perpendicular to the hymenial surface, some lengthening beyond the hymenium and giving the hairy appearance to the apothecia. Paraphyses exceeding the asci, cylindric-filiform, 3-4 $\mu \mathrm{m}$ diam., septate, sometimes branched, containing hyaline vacuoles, usually curved and somewhat inflated at the tips. Asci 55-90 × 25-37 $\mu \mathrm{m}$, usually 8 -spored but with only two to six maturing ascospores, inamyloid, operculate, broadly clavate to saccate, thick-walled, with an abruptly contracted, short stalk and a rounded apex. Ascospores (15-) 16-21 (-23) × 13-16 (-18) $\mu \mathrm{m}$, rarely subglobose or ellipsoidal, usually broadly ellipsoidal $(\mathrm{Q}=1.06-1.43 ; \mathrm{Q}=1.22)$, hyaline and smooth in the early stages, becoming brown, irregularly biseriate, surrounded by a gelatinous sheath which disappears at maturity, lacking oil drops, with a thick, even, rough, pitted pigment.

Material examined - Italy, Pisa, Monteverdi Marittimo, Podere Allumiere, 200 $m$ a.s.l., six scattered, superficial specimens, on rabbit dung in a damp chamber culture, F. Doveri, 25.3.11, 306.4-Monteverdi Marittimo, CLSM 006.11.

Notes - Ascobolus perforatus was erected by van Brummelen (1981) as a new name (nomen novum) based on Ascodesmis canina Jeng \& Krug, whose morphological features appeared to fully match those of Ascobolus sect. Pseu-dascodesmis Brumm. (Ascobolaceae). Growth on dung, small gymnohymenial apothecia with a scarcely developed excipulum, pigmented and globose to broadly ellipsoidal ascospores with ornamentations, and broadly clavate to saccate, inamyloid asci, are the main features of this section (van Brummelen 1967), which is similar to the genus Ascodesmis (inde nomen), in Ascodesmidaceae J. Schröt. Ascodesmis, how-ever, can be distinguished by its minute asco-mata (usually less than $200 \mu \mathrm{m}$ wide) growing gregarious or even crowded and forming crusts rather than scattered, and by an even more reduced or missing excipulum, often restricted to a few basal hyphae. The absence of excipu-lum justifies this kind of ascomata being called "athecia" (from Latin = "lacking a receptacle") (Weber et al. 1997). Apothecioid, or better cleistothecioid ascomata, opening in a late maturity phase are, on the contrary, typical of sect. Pseudascodesmis. They are clearly obser-vable under a stereomicroscope and appear very similar to pale ascomata of Iodophanus Korf species.

Besides A. perforatus, sect. Pseudascodesmis includes only one other species, i.e., Ascobolus reticulatus Brumm. The differences between the two species are slight: A. perforatus has somewhat larger ascospores on average [15-21 × 12-16 $\mu \mathrm{m}$ (Jeng \& Cain 1976)] versus $13-19.5 \times 13-15.5 \mu \mathrm{m}$ (van Brummelen 1967)], with an episporium ornamented with holes and pores rather than with a wide-meshed, almost complete reticulum joining low tubercles (Figs 11-12). We have observed additional differences in our Italian isolates, A. reticulatus having longer (130-160 $\mu \mathrm{m}$, Doveri 2007) and clavate rather than basically saccate asci with slenderer instead of abruptly contracted stalks, and usually all ascospores reaching maturity in 8-spored asci (Fig 12). A. reticulatus is a rare species, but 


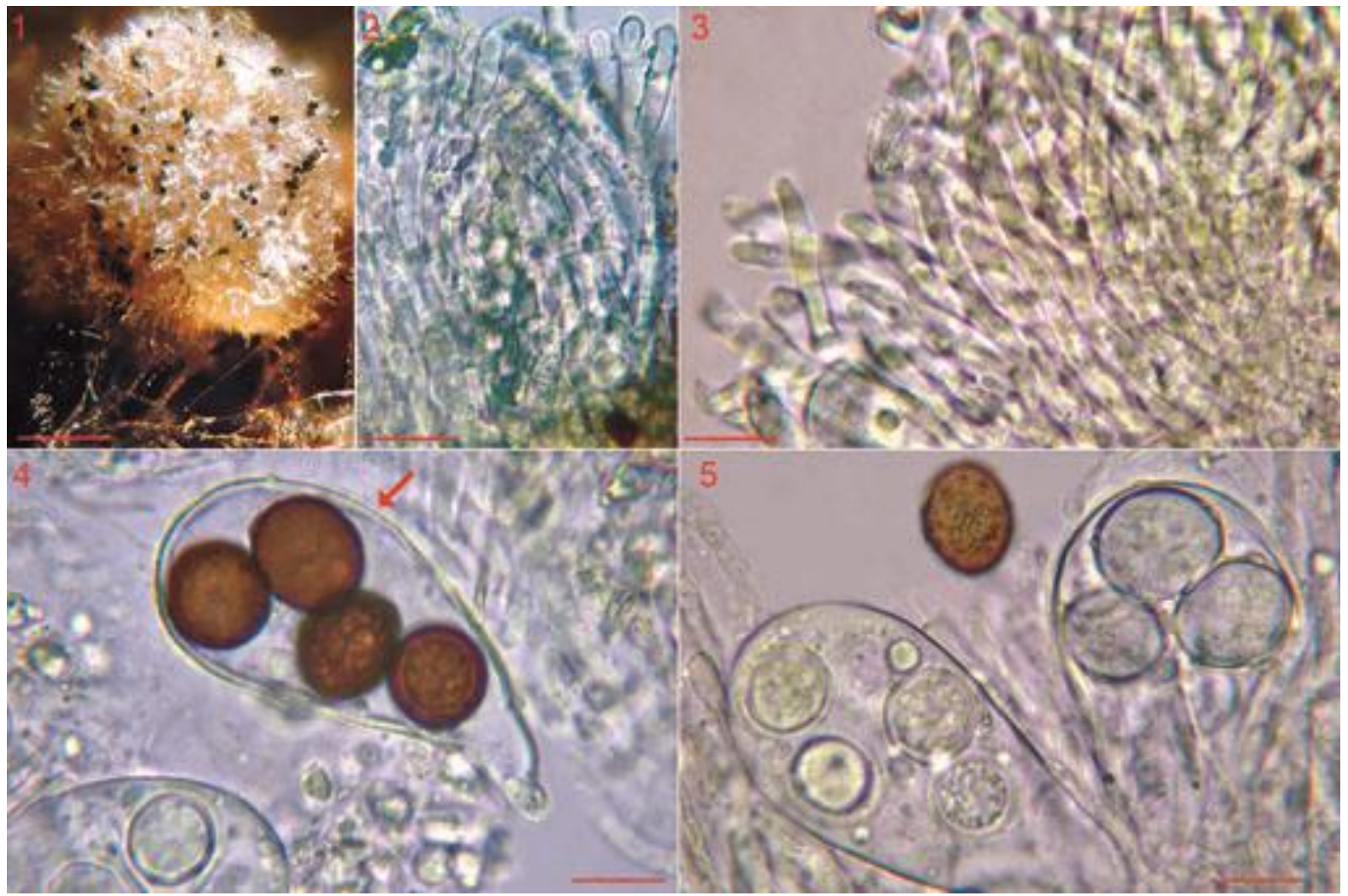

Figs 1-5 - Ascobolus perforatus CLSM 006.11. 1 Ascoma on dung. 2 Ectal excipulum: a textura prismatica with some emerging hyphae. 3 Paraphyses. 4 Ascus with only four mature ascospores. 5 Immature asci and one, free mature ascospore. Bars $1=200 \mu \mathrm{m}, 2=10 \mu \mathrm{m}, 3-5=15 \mu \mathrm{m}$.

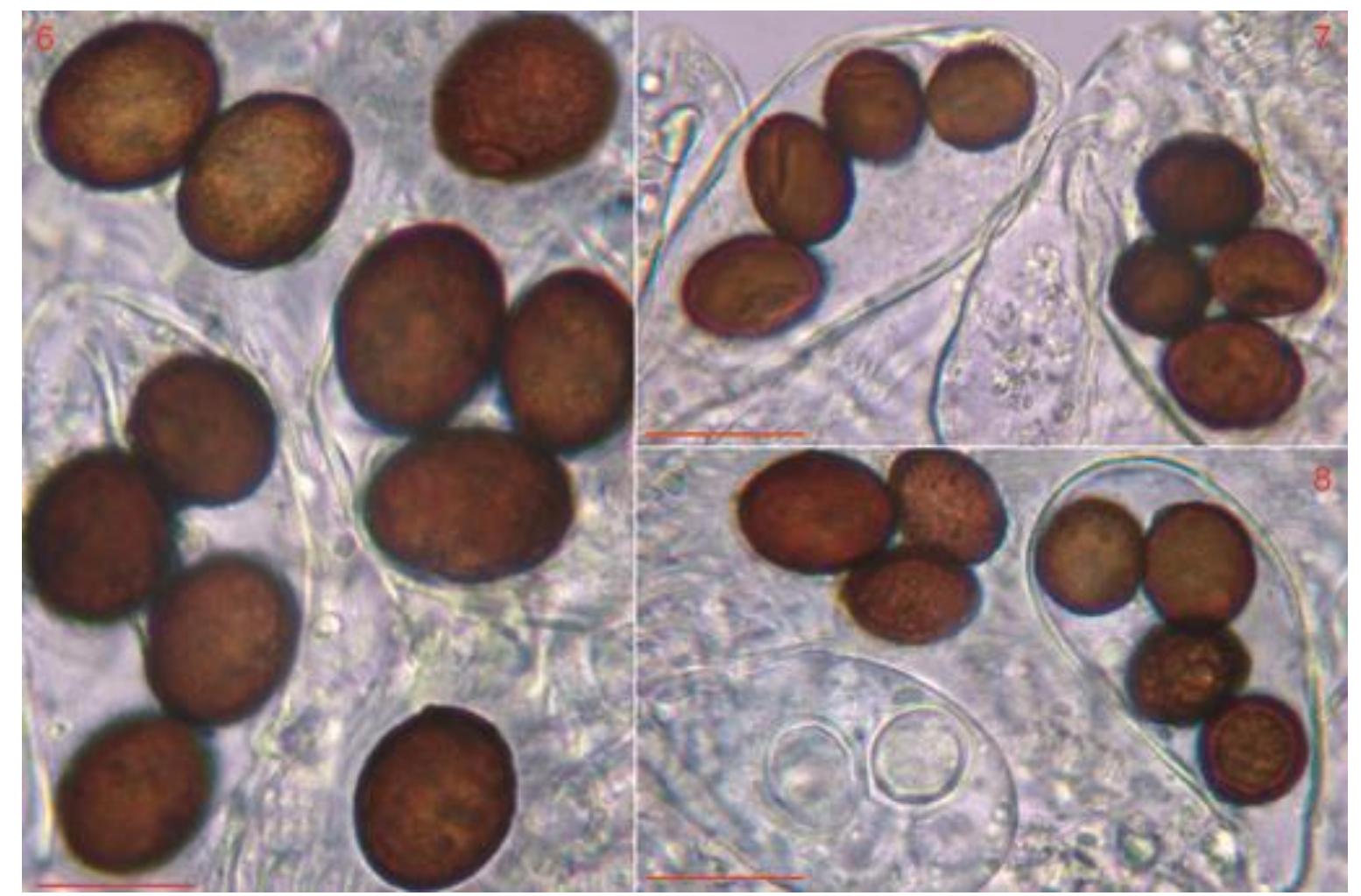

Figs 6-8 - Ascobolus perforatus. CLSM 006.11. Asci with mature, pitted ascospores. Bars $6=15$ $\mu \mathrm{m}, 7-8=20 \mu \mathrm{m}$ 


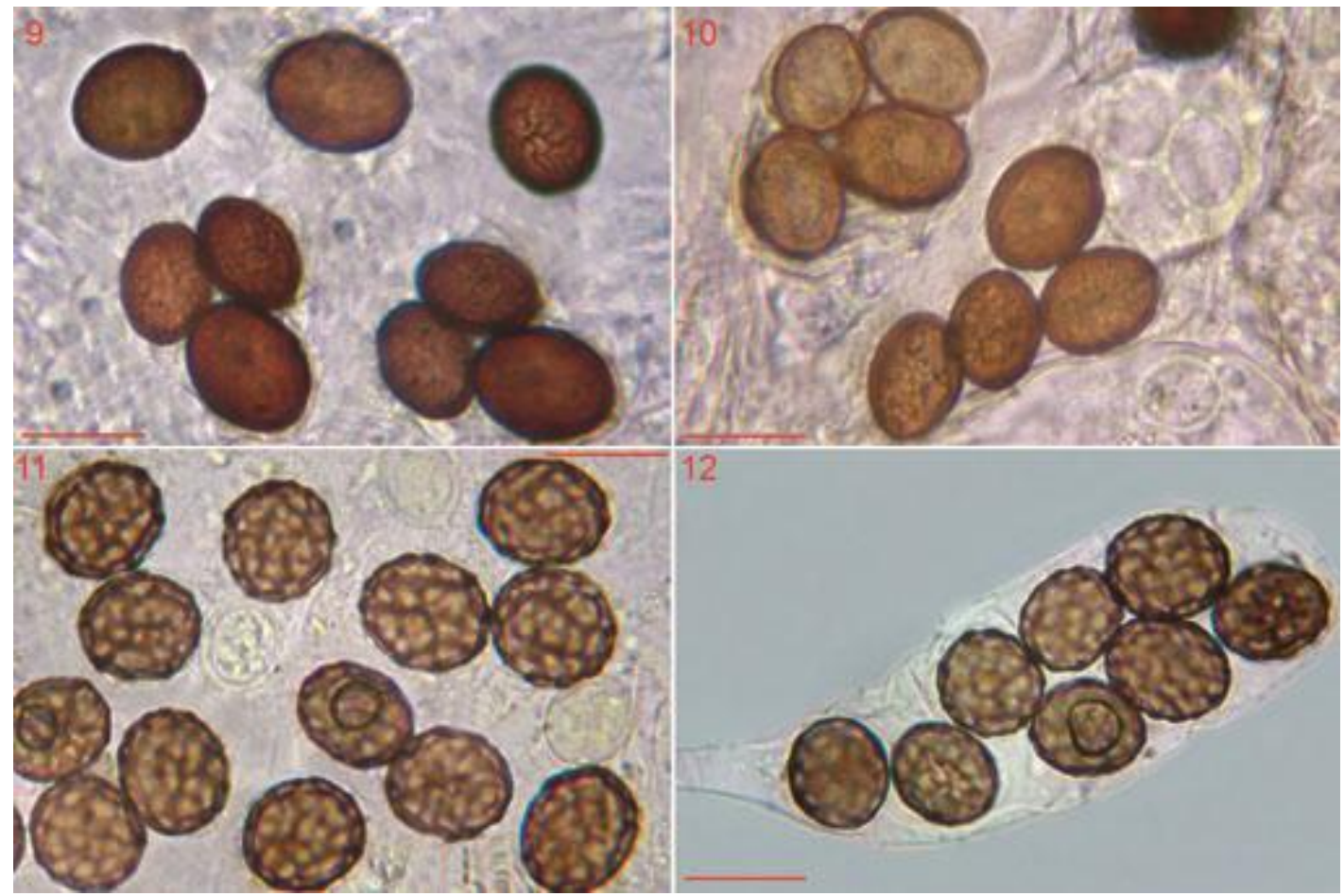

Figs 9-10 - Ascobolus perforatus. CLSM 006.11. 9 Free mature ascospores. 10 Pitted ascospores inside asci. Figs 11-12 - Ascobolus reticulatus. CLSM 004.06 11 Free reticulate ascospores. 12 8spored ascus with mature ascospores. Bars 9-12=15 $\mu \mathrm{m}$.

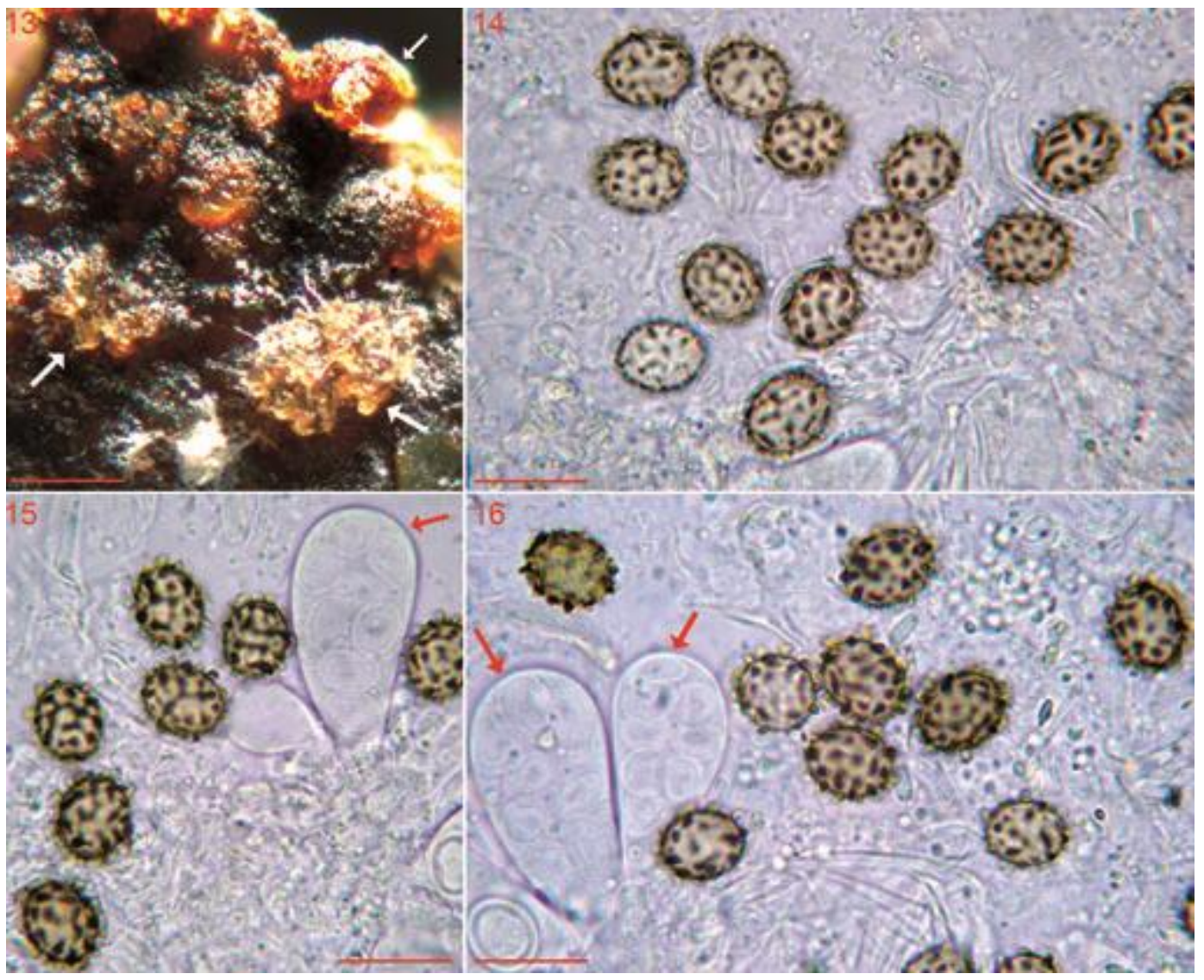

Figs 13-16 - Ascodesmis nigricans. CLSM 03897 bis. 13 Ascomata on dung (arrows) 14-16 Free mature ascospores, and 8-spored immature asci (arrows). Bars $13=150 \mu \mathrm{m}, 14-16=15 \mu \mathrm{m}$. 

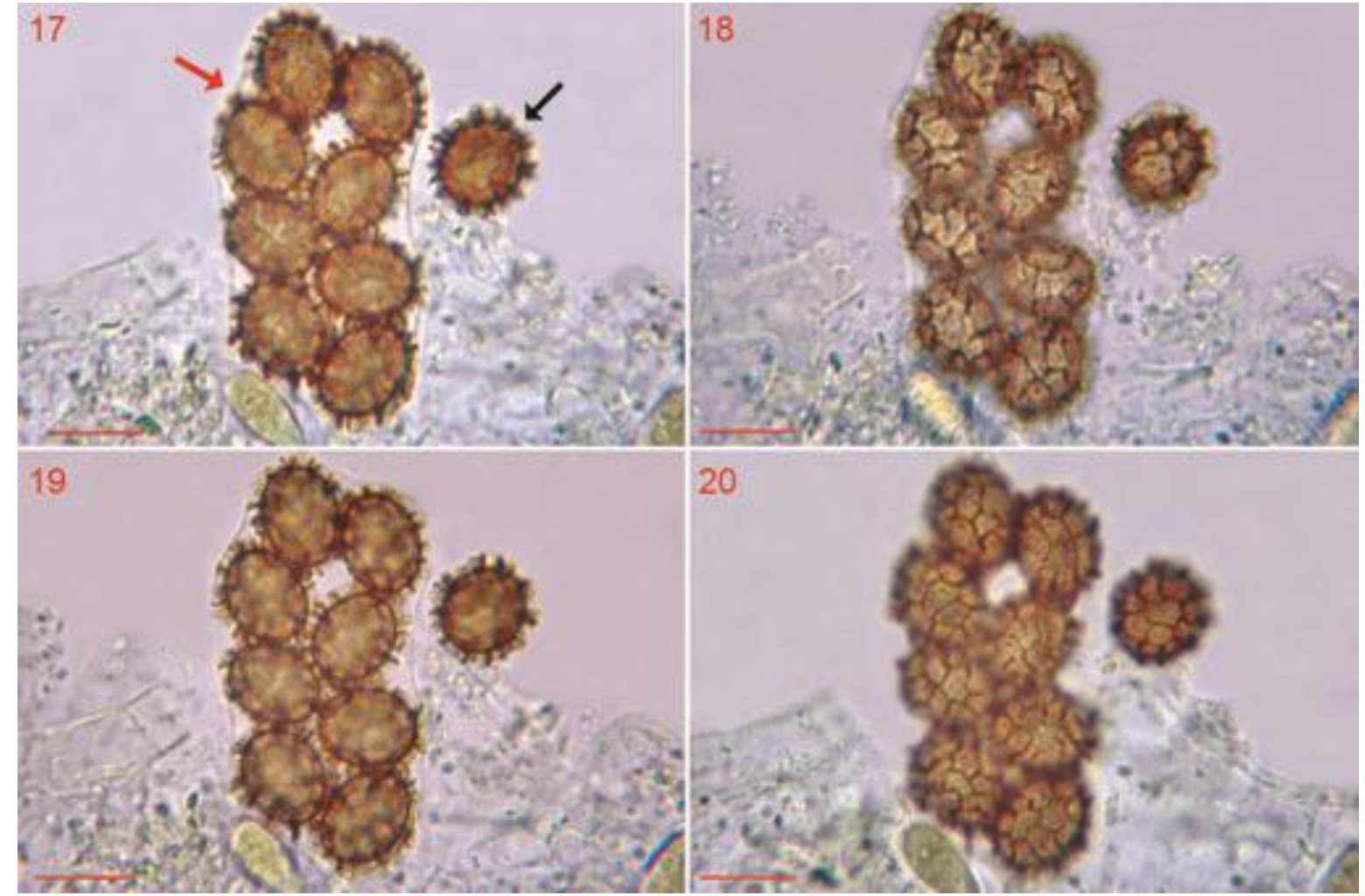

Figs 17-20 - Ascodesmis microscopica. CLSM 02899. One free, mature ascospore (black arrow) beside an 8-spored ascus (red arrow), containing ascospores in four different focuses. Bars $=13 \mu \mathrm{m}$.
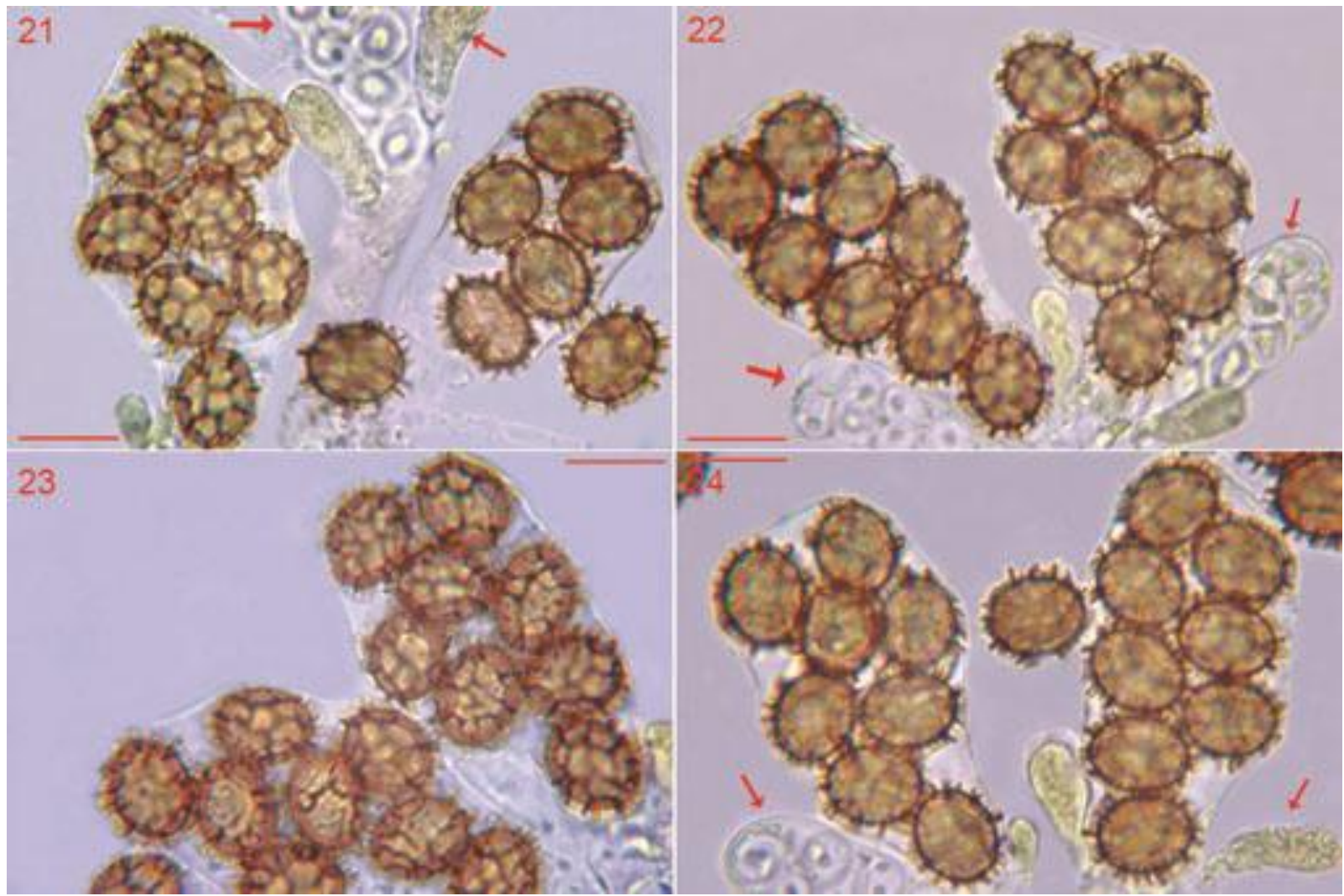

Figs 21-24 - Ascodesmis microscopica. CLSM 02899. 8-spored asci containing mature ascospores in four different focuses. Bars $=13 \mu \mathrm{m}$. 


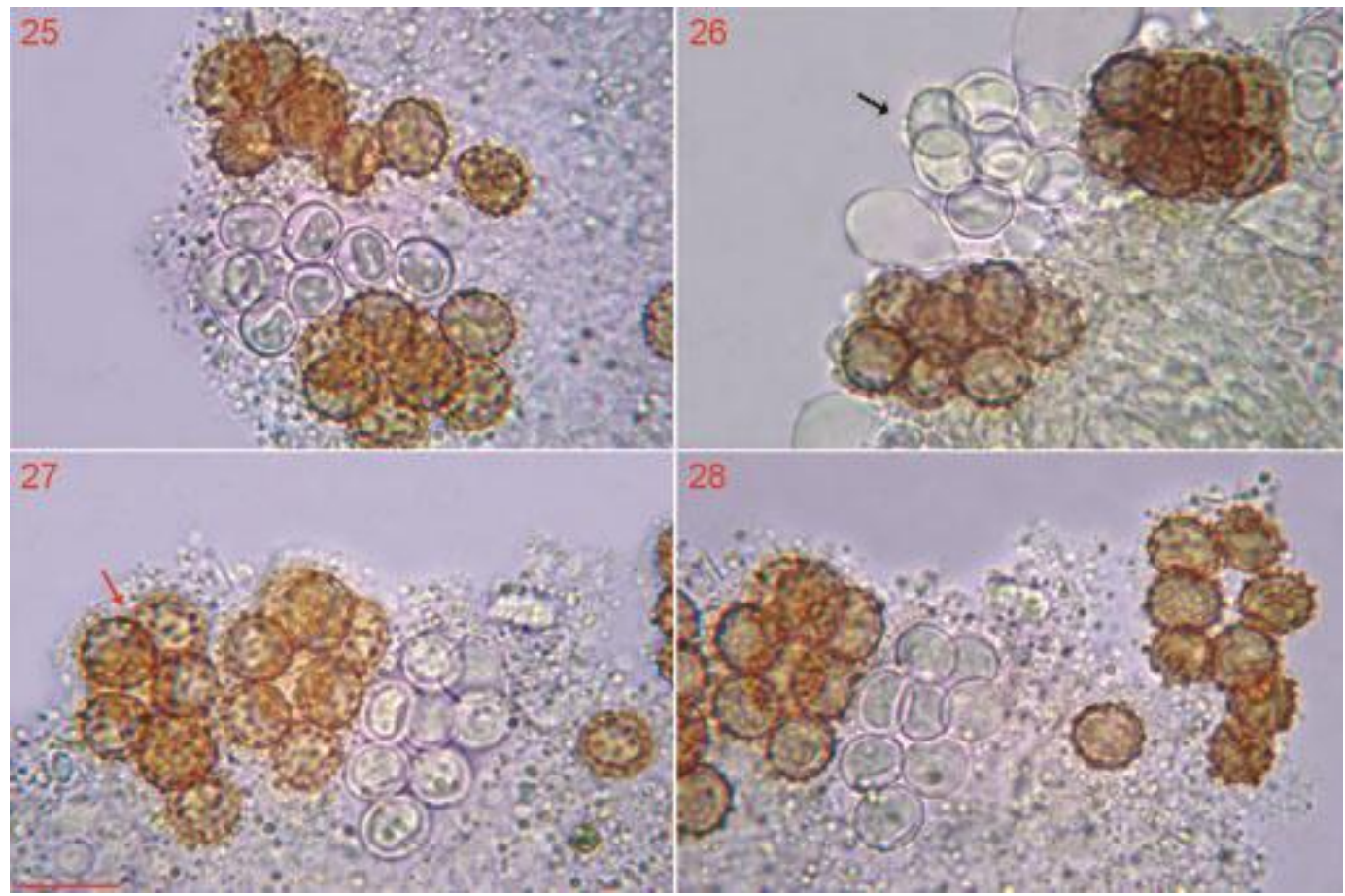

Figs 25-28 - Ascodesmis nana. CLSM 01599. Mature (red arrow) and immature (black arrow) ascospores inside 8-spored asci. Bar $=15 \mu \mathrm{m}$.

less than $A$. perforatus, and it has been reported so far from Germany on giraffe dung (van Brummelen 1967), Japan on Barbary sheep (Minoura et al. 1978), Taiwan on sheep and deer (Wang 1996, 1999), Italy on goose (Doveri 2007), and Spain on rabbit (Vicente et al. 2010).

A. perforatus has been reported only twice before, from Venezuela on dog dung (Jeng \& Cain 1976) and from Iraq on cow dung (Abdullah \& Alutbi 1993). Ours is the third record worldwide and the first combined record of $A$. perforatus and A. reticulatus from the same country.

We also collected from Italy (Doveri et al. 2000, Doveri 2004) three of the four recognized European species of Ascodesmis, the quite common (ten strains) A. nigricans Tiegh. (Figs 13-16), the less common (three strains) A. microscopica (H. Crouan \& P. Crouan) Seaver (Figs 17-24) and the rare (one strain) A. nana Brumm. (Figs 25-28).

\section{References}

Abdullah SK, Alutbi SD. 1993 - Additions to coprophilous fungi of Iraq III. Ascobolaceae: Pezizales. Basrah
Journal of Science 11, 33-44.

Brummelen J van. 1967 - A world-monograph of the genera Ascobolus and Saccobolus (Ascomycetes, Pezizales). Persoonia, supplement Vol. I. Rijksherbarium, Leiden.

Brummelen J van. 1981 - The genus Ascodesmis (Pezizales, Ascomycetes). Persoonia $11,333-358$.

Doveri F. 2004 - Fungi Fimicoli Italici. A.M.B., Vicenza.

Doveri F. 2007 - An updated key to coprophilous Pezizales and Thelebolales in Italy. Mycologia Montenegrina 10, 5582.

Doveri F. 2010 - Occurrence of coprophilous Agaricales in Italy, new records, and comparison with their European and extraeuropean distribution. Mycosphere 1(2), 103-140.

Doveri F. 2011 - Addition to "Fungi Fimicoli Italici": An update on the occurrence of coprophilous Basidiomycetes and Ascomycetes in Italy with new records and descriptions. Mycosphere 2(4), 331-427.

Doveri F, Cacialli G, Caroti V. 2000 - Guide pour l'identification des Pezizales fimi- 
coles d'Italie. Contribution à l'étude des champignons fimicoles-XXXII. Documents Mycologiques 30(117118), 3-97.

Doveri F, Pecchia S, Vergara M, Sarrocco S, Vannacci G. 2012 - A comparative study and relationship with Onygenales of Neogymnomyces virgineus, a new keratinolytic species from dung. Fungal Diversity 52, 13-34.

Jeng RS, Cain RF. 1976 - A new species of Ascodesmis from Venezuela. Mycotaxon 3, 391-395.

Minoura K, Matsumura E, Morinaga T. 1978 - Notes on coprophilous discomycetes in Japan (II). Transactions of the Mycological Society of Japan 19, 355361.

Richardson MJ. 2001 - Diversity and occurrence of coprophilous fungi. Mycological Research 105, 387-402.
Richardson MJ, Watling R. 1997 - Keys to fungi on dung. British Mycological Society, Stourbridge.

Vicente JF, Iglesias P, Hidalgo F, Oyarzabal M. 2010 - Aportaciones al conocimiento micológico de la Isla de La Palma II y una nueva especie de Tricholosporum. Errotari 7, 84-131.

Wang Y-Z. 1996 - Notes on coprophilous discomycetes from Taiwan. III. Bulletin of the National Museum of Natural Science 7, 131-136.

Wang Y-Z. 1999. The coprophilous discomycetes of Taiwan. Bulletin of the National Museum of Natural Science 12, 49-74.

Weber NS, Trappe JM, Denison WC. 1997 Studies on western American Pezizales. Collecting and describing ascomata-macroscopic features. Mycotaxon $61,153-176$. 